\title{
THE RENEWABLE SOURCES OF ENERGY AND THE ROMANIAN ENERGY SECURITY
}

\author{
Ionut Alin CÎRDEI \\ “Nicolae Bălcescu”,Land Forces Academy Sibiu, Romania \\ cirdei_alin@yahoo.com
}

\begin{abstract}
Energy security is a matter of particular importance to all the world's states, whether they are producers or consumers of energy resources. For a long time, fossil energy resources have been the only source of energy used on a planetary scale. When mankind realized that fossil energy resources are a finite source of energy and that their intensive use causes many environmental problems, the most important of which is related to global warming, they have tried to find alternative sources of energy. Thus, concerns have arisen about the use of renewable energy on a wider scale, with both individual concerns of states that have potential in this area and collective concerns, such as at EU level, which has proposed by 2020, the share of energy from renewable sources used by the Union states is at least 20\% of total consumption. Renewable energy resources may be an alternative to fossil fuels, but at the same time it has a number of limitations and vulnerabilities. Ensuring energy security means a comprehensive approach, understanding of limitations and reducing vulnerabilities
\end{abstract}

\section{Keywords: energy security, renewable energy, fossil, vulnerabilities.}

\section{Introduction}

Modern society is witnessing the transformation of the international security environment. The security environment "is in a rapid and continuous remodeling, marked by symmetrical and predictable changes, but also by atypical, hybrid changes, which are at least surprising"1]. Under these conditions, collective and national security can not be addressed only from a military or political - military perspective, but must be addressed in a comprehensive, multidimensional way, and one of the essential dimensions of security is energy security. Achieving energy security is a major concern of all states, whether they are producing or consuming energy resources. Energy security does not mean energy independence, because in the present society this is more an utopia. Energy security can be achieved even under the conditions of a clear dependence on imported energy resources, especially in the situation of the states in the European Union. Firstly, energy dependence is reciprocal, meaning that some states depend on imported energy resources to a lesser or greater extent, just as energy resource providers depend on consumers for their marketing and to ensure economic growth and development. On the other hand, energy dependence is not a major risk, if there are more suppliers, if there are more sources of supply. Moreover, at the level of the European Union, the problem of energy dependence is also approached from the point of view of providing mutual support in times of crisis, between the states from the Union and in this respect, more and more, the emphasis is increasingly on the interconnection of the energy systems and of the Member States' fossil energy 
transport systems so that there is the possibility of ensuring a two-way flow for all these resources.

However, ensuring the energy resources necessary for the functioning of society at an affordable price, in sufficient quantities, at the right time, given that hydrocarbon resources are reduced as time passes, must be a major concern for all states. Starting from this situation and taking into account the major impact of the use of fossil energy resources on the environment, given the fact that the society has become aware of the need for sustainable development, it is necessary to use the renewable energy resources as widely and efficient as possible, to the point where they become the main source of energy, but not the only source. At the level of the European Union, the first steps have been taken in order to establish clear lines of action that aim at 2020 that at least 20\% of EU-produced energy to come from renewable sources, but taking into account the potential of each country to produce energy from renewable sources. Renewable energy can represent an appropriate response to the problem of pollution, the issue of climate change and can provide a long-term solution to the inevitable depletion of traditional energy sources.

\section{Addressing the EU's renewable energy issue}

At the EU level, concerns have been raised to ensure energy security, reduce pollution, increase energy efficiency, diversify energy sources, focusing on the promotion of energy from renewable sources, etc. These concerns materialized in 2009, when Directive 2009/28 / EC of the European Parliament and of the Council on the promotion of the use of energy from renewable sources have been adopted. This directive, which refers to a package of measures to be implemented by the Member States in order to allow them to promote the renewable energy and to achieve the objectives in this field, amended and subsequently repealed Directives 2001/77 / EC and 2003/30 / EC. The Directive defines renewable energy as „energy from renewable non-fossil sources, namely wind, solar, aerothermal, geothermal, hydrothermal and ocean energy, hydropower, biomass, landfill gas, sewage treatment plant gas and biogases" [2] and sets as target for the European Union for 2020 to produce $20 \%$ of the total energy consumed from renewable sources and sets country-specific targets, depending on the initial share of renewable energy in total consumption and the internal potential of each country. Through this directive, the European Union establishes mechanisms for cooperation between states, reporting mechanisms, control mechanisms and a tool for assessing progress in this area and encourages states to take all necessary measures to increase the share of renewable energy in total energy consumed, focusing on energy-consuming sectors and encouraging increased energy efficiency. It should not be forgotten that the shift from fossil energy to renewable energy must be done gradually to allow states to adapt to new conditions, adapt their economy, increase energy efficiency, etc., so that these measures be sustainable. The EU's objective is that in 2020 at least $20 \%$ of the energy consumed at Union level be represented by green energy, starting from the situation in 2005, when the share of green energy was only $9 \%$ of the total. At present, there are EU countries such as Bulgaria, Croatia, the Czech Republic, Denmark, Estonia, Finland, Lithuania, Romania, Sweden, Hungary, which have already exceeded the target for $2020 \%$, but also countries such as Belgium, Cyprus, France, Ireland, Luxembourg, Malta, the Netherlands that are far from this target, while the European average is around $17 \%$. The share of energy from renewable sources in the total EU energy consumption is presented in detail in Table no. 1. 


\begin{tabular}{|c|c|c|c|}
\hline Country & $\begin{array}{l}\text { Share of renewable } \\
\text { energy from total } \\
\text { consumption in } 2005\end{array}$ & $\begin{array}{l}\text { Share of renewable } \\
\text { energy from total } \\
\text { consumption in } 2016\end{array}$ & $\begin{array}{c}\text { Target share of } \\
\text { renewable energy } \\
\text { from total } \\
\text { consumption in } 2020\end{array}$ \\
\hline EU28 & $9,0 \%$ & $17,0 \%$ & $20,0 \%$ \\
\hline Austria & $23,7 \%$ & $33,5 \%$ & $34,0 \%$ \\
\hline Belgium & $2,3 \%$ & $8,7 \%$ & $13,0 \%$ \\
\hline Bulgaria & $9,4 \%$ & $18,8 \%$ & $16,0 \%$ \\
\hline Croatia & $23,8 \%$ & $28,3 \%$ & $20,0 \%$ \\
\hline Cyprus & $3,1 \%$ & $9,3 \%$ & $13,0 \%$ \\
\hline Czech Republic & $7,1 \%$ & $14,9 \%$ & $13,0 \%$ \\
\hline Denmark & $16,0 \%$ & $32,2 \%$ & $30,0 \%$ \\
\hline Estonia & $17,5 \%$ & $28,8 \%$ & $25,0 \%$ \\
\hline Finland & $28,8 \%$ & $38,7 \%$ & $38,0 \%$ \\
\hline France & $9,6 \%$ & $16,0 \%$ & $23,0 \%$ \\
\hline Germany & $6,7 \%$ & $14,8 \%$ & $18,0 \%$ \\
\hline Greece & $7,0 \%$ & $15,2 \%$ & $18,0 \%$ \\
\hline Hungary & $6,9 \%$ & $14,2 \%$ & $13,0 \%$ \\
\hline Ireland & $2,9 \%$ & $9,5 \%$ & $16,0 \%$ \\
\hline Italy & $7,5 \%$ & $17,4 \%$ & $17,0 \%$ \\
\hline Latvia & $32,3 \%$ & $37,2 \%$ & $40,0 \%$ \\
\hline Lithuania & $16,8 \%$ & $25,6 \%$ & $23,0 \%$ \\
\hline Luxembourg & $1,4 \%$ & $5,4 \%$ & $11,0 \%$ \\
\hline Malta & $0,1 \%$ & $6,0 \%$ & $10,0 \%$ \\
\hline Netherlands & $2,5 \%$ & $6,0 \%$ & $14,0 \%$ \\
\hline Poland & $6,9 \%$ & $11,3 \%$ & $15,0 \%$ \\
\hline Portugal & $19,5 \%$ & $28,5 \%$ & $31,0 \%$ \\
\hline Romania & $17,3 \%$ & $25,0 \%$ & $24,0 \%$ \\
\hline Slovak Republic & $6,4 \%$ & $12,0 \%$ & $14,0 \%$ \\
\hline Slovenia & $16,0 \%$ & $21,3 \%$ & $25,0 \%$ \\
\hline Spain & $8,5 \%$ & $17,3 \%$ & $20,0 \%$ \\
\hline Sweden & $40,6 \%$ & $53,8 \%$ & $49,0 \%$ \\
\hline $\begin{array}{l}\text { United } \\
\text { Kingdom }\end{array}$ & $1,3 \%$ & $9,3 \%$ & $15,0 \%$ \\
\hline
\end{tabular}

Table 1: Renewable energy consumed in EU [3]

The issue of increasing energy production from renewable sources is all the more important because, according to data published by Eurostat, the EU's dependence on imported energy resources in the year 2016 was $53.6 \%$, with states with a degree of dependence between $70 \%$ and $100 \%$, such as Belgium, Greece, Spain, Italy, Cyprus, Lithuania, Luxembourg, Malta, and with states with low dependency, ranging from $0 \%$ to 25\%, such as Denmark, Estonia, Romania, Iceland. Hence the importance that Member States have to give to renewable energy, which must be seen not only as a way to protect the environment and reduce carbon emissions in the atmosphere, but also as a way to reduce dependence on energy resources imports and, consequently, to achieve medium- and long-term energy security, as 
long as the issue is addressed in a comprehensive manner.

\section{Contribution of renewable energy resources to Romania's energy security}

All the world's states are interested in ensuring their own energy security. Moreover, the Member States of the European Union must also be concerned about the provision of common energy security, seen as a prerequisite for their own energy security, as the focus of efforts and the sharing of resources and information reduces vulnerabilities and decreases dependence on external sources of supply, even in the face of a major crisis.

Romania is one of the EU member states with a rather low energy dependence, which has important fossil energy resources and has a very important renewable energy potential, the potential it wants to use to contribute to its own energy security and to the Union energy security. Romania's engagement in the process of achieving energy security is based on Romania's Energy Security Strategy for the period 2007-2020. According to this, Romania must meet its own energy objectives and, at the same time, contribute to the achievement of European objectives, in view of increasing competitiveness, sustainable development and achieving energy security. In this respect, "Romania will act especially in the field of energy efficiency and in the field of renewable energy sources, actions aimed at promoting energy efficiency and renewable energy sources, which will contribute both to reducing the negative impact on the environment and to increasing the security in supply, diminishing Romania's dependence on energy imports "[4]. Romania's concerns in this respect are visible, as well as the increase in the share of renewable energy in total energy consumption, from $17.3 \%$ in 2005 to $25 \%$ in 2016, when the EU target for our country for 2020 is $24 \%$. In Romania, the need for energy resources is ensured both from domestic and imported production, the imported quantities vary depending on the type of resources and the period of the year. Thus, according to statistical data [5], Romania, in 2016, had oil reserves of 600 million barrels, a production of 78 thousand barrels per day, compared to a consumption of 200 barrels of oil per day, which results in a degree of dependence on imports of $61 \%$. According to the same sources, the situation in the field of natural gas and renewable energy is the following [6]: Romania, at the end of 2016, had a natural gas reserve of 99 billion cubic meters, an annual production of 9.33 billion cubic meters and a consumption of 10, 48 billion cubic meters, resulting in a degree of dependence very low, about $11 \%$, one of the lowest in Europe. As far as renewable energy is concerned, at the end of 2016, Romania had a 1372 MW photovoltaic power production capacity and a $3182 \mathrm{MW}$ wind power capacity. These quantities highlight Romania's high potential in this area, as well as the progress made by our country for the development of renewable energy production capacities. Regarding the actual energy production in Romania, we can state that our country has the possibility to ensure the necessary energy from the domestic production and, at the same time, to provide important quantities of energy for export, in order to compensate for the deficit in the neighboring states. With the interconnection of European energy grids, our country will be able to be a major supplier of electricity to Union states in peak production periods when weather conditions allow. For example, on February 27, 2018, Romania produced $11018 \mathrm{MW}$ of electricity, while the consumption was 9466 MW, resulting in an availability for exports of $1407 \mathrm{MW}$. According to the available data on the national energy system, we find that out of the total energy produced at that time (Figure 1), 13\% was nuclear energy, $45 \%$ fossil energy and $42 \%$ renewable energy. 


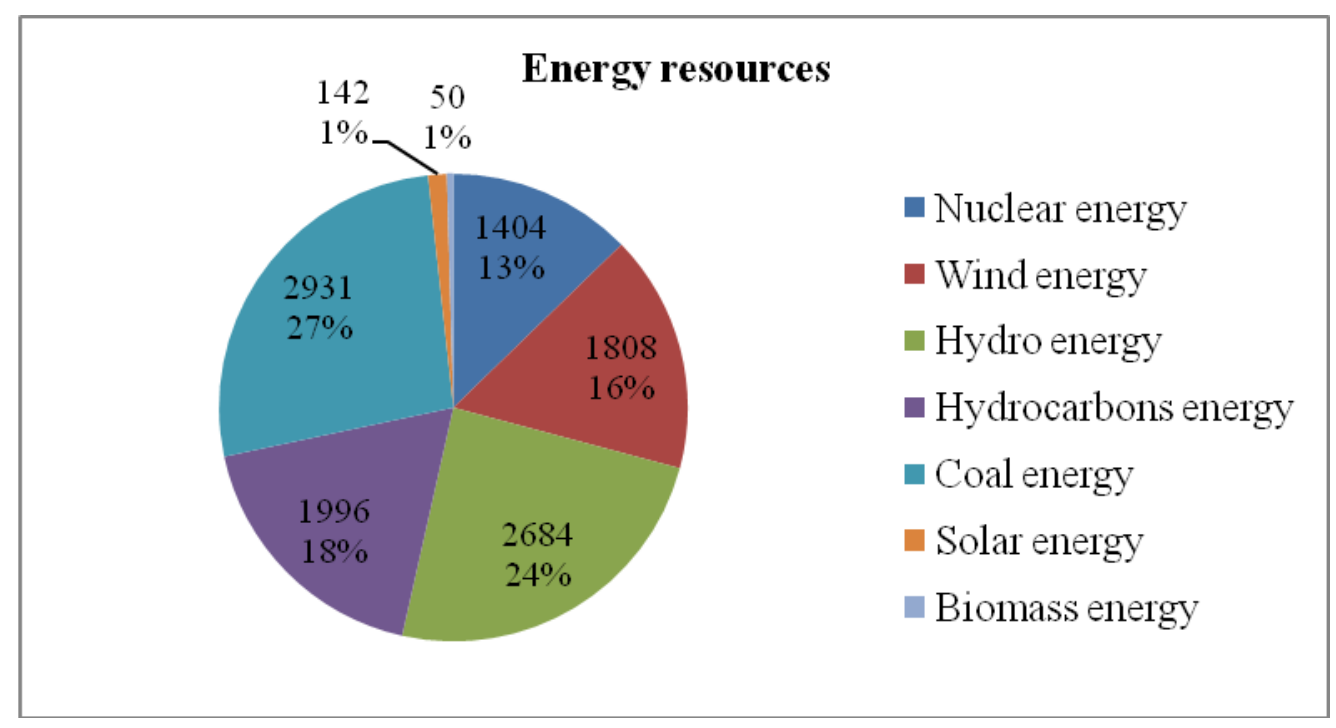

Figure 1: The resources used in the production of electricity in Romania (as of 2018-02-27, 11:16:4)[7]

The renewable energy used in Romania represents a significant percentage of the daily requirement, but the actual quantities vary depending on a number of factors, such as the sunshine period, the intensity of the sunlight, the speed and the constant of the winds, the amount of precipitation fallen, etc. Consequently, the development of renewable energy capabilities, beyond the obvious benefits of protecting the environment, reducing carbon emissions, limiting the effects of climate change, etc., should still be seen with some reservations, as under current conditions the growth the share of renewable energy in total energy consumption would give rise to new vulnerabilities due to the unpredictability of using renewable sources. In order for Romania to ensure its energy security we consider that it is necessary to increase the share of energy from renewable sources in a controlled manner based on calculations that take into account not only the ecological and strict economic dimension but also the sustainability on long term and the flexibility of such a system due to the large fluctuations in the quantities produced, the impossibility of storing this energy, the difficulty of offsetting from other sources. Therefore, it is necessary to maintain and further develop capacities to produce energy from conventional sources, such as coal, oil or natural gas, as they are less exposed to fluctuations. For conventional energy sources to remain competitive, it is necessary to increase the efficiency of energy complexes, to reduce their pollution and to introduce them into an integrated energy system, allowing synergic operation of all systems. A too high share of energy from renewable sources, given that the countries around Romania do not have a very large capacity to compensate for the temporary energy shortage, even if the number of interconnections and the capacity of the interconnection system increases, would create a long term vulnerability for our country. Therefore, a balance between renewable and conventional energy needs to be identified beyond what needs to be done in order to meet the essential requirements: ensuring energy security, sustainable development and increasing competitiveness [8]. Romania needs to focus on increasing energy efficiency, increasing energy system 
performance, finding an optimal energy mix for our country, taking into account the energy potential, the need to increase the share of renewable energy, and the impact on the environment and the possibility of ensuring medium- and long-term energy security.

\section{Conclusions}

Renewable energy resources are an important source of energy and are seen as saving solutions for the whole of mankind, because they are practically inexhaustible and their use has a low environmental impact. However, renewable energy resources have a number of disadvantages, such as:

- For efficient use, high initial costs are needed to develop and implement technologies;

- Getting energy from renewable sources is dependent on weather conditions, such as the duration of sunshine, wind speed, rainfall, etc.;

- To be effective, they must be constructed in a relatively large number, in the form of wind or photovoltaic parks;

- Making these production facilities can have a major impact on the environment and on the human communities in the area due to the natural imbalances they can create;

- Biomass can have negative effects, such as: the decrease of the areas cultivated for food production, the increase of the carbon dioxide emissions, due to its burning or processing;

- The impossibility of storing energy produced from these sources in peak periods to compensate periods of lower production;

- Underperforming technologies that don't allow the use of large-scale renewable energy in energyintensive sectors such as transport;
Renewable energy is important in the energy mix of any country, irrespective of its size or location on the international scene, and increasing the share of this energy in the energy mix can be a means of limiting dependence on external energy sources and to ensure energy security. However, in the case of Romania, we believe that energy security must be achieved by developing an efficient energy system, integrated and interconnected with the European energy systems and combining, in an optimal way, both energy from conventional sources, and renewable energy.

Renewable energy can, in our opinion, create the conditions for achieving energy security, but it cannot guarantee it, as they are not a constant source of supply, being influenced by the factors mentioned above. Therefore, it is necessary to develop capacities to produce energy from renewable sources to a level of about $60 \%$ of the total, but to maintain a high potential for producing energy from other sources such as fossil and nuclear, in order to compensate for possible deficiencies and to be able to intervene properly in the system. Even though renewable energy resources can be attractive in many ways, they cannot be considered as a source of miraculous energy, which is the answer to the energy problem of mankind. Conventional energy resources, with all their disadvantages, will play an important role in ensuring the energy security of any state and especially of Romania in the medium and long term, at least until the discovery of an inexhaustible, safe and environmentally friendly fuel. The key to ensuring energy security is the creation of an integrated, interconnected, diversified system in which renewable energy can play an important role, but the system must at no time depend exclusively on them. 


\section{References}

[1] Aurelian RAȚIU, Amenințări și factori de risc la adresa securității globale, Editura Academiei Forțelor Terestre "Nicolae Bălcescu", Sibiu, 2016, p. 34.

[2] Jurnalul Oficial al Uniunii Europene L 140/16, Directiva 2009/28/CE a Parlamentului European și a Consiliului din 23 aprilie 2009 privind promovarea utilizării energiei din surse regenerabile, de modificare și ulterior de abrogare a Directivelor 2001/77/CE și 2003/30/CE, p. 27, available on http://eur-lex.europa.eu/legalcontent/RO/TXT/?uri=celex\%3A32009L0028 .

[3] http://ec.europa.eu/eurostat/web/energy/data/shares.

[4] Strategia energetică a României pentru perioada 2007 - 2020, actualizată pentru perioada 2011 - 2020, p. 48, available on http://www.minind.ro/energie/STRATEGIA_energetica_actualizata.pdf.

[5] ENI, World oil review 2017, available at https://www.eni.com/docs/en_IT/enicom/company/fuel-cafe/WORLD-OIL-REVIEW2017-Volume-1.pdf.

[6] ENI, World gas and renewable review 2017, available at https://www.eni.com/docs/en_IT/enicom/company/fuel-cafe/WORLD-GAS-ANDRENEWABLES-2017-Volume-2.pdf

[7] The production and consumption of electricity in Romania, according to http://version1.sistemulenergetic.ro/.

[8] Guvernul României, Strategia Naţională pentru Dezvoltare Durabilă a României, Orizonturi 2013-2020-2030, București 2008, pp. 42 - 43, available at http://www.mmediu.ro/beta/domenii/dezvoltare-durabila/strategia-nationala-a-romaniei2013-2020-2030/ . 